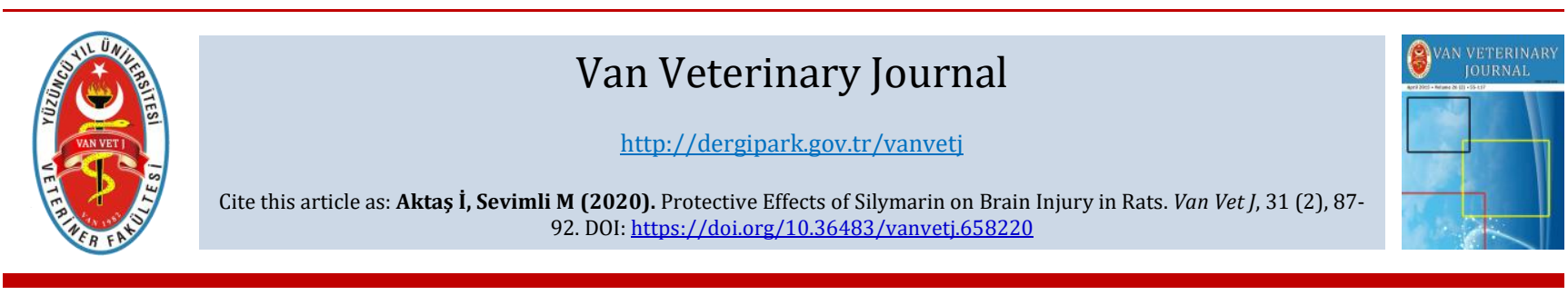

\title{
Protective Effects of Silymarin on Brain Injury in Rats
}

\author{
İbrahim AKTAŞ1@ Murat SEVIMLí \\ ${ }^{1}$ Adiyaman University, School of Health Services, Department of Pharmacology, Adiyaman, Turkey \\ 2 Süleyman Demirel University, Faculty of Medicine, Department of Histology and Embryology, Isparta, Turkey \\ Received: 11.12 .2019 \\ Accepted: 17.04 .2020
}

ABSTRACT In this study, we evaluated the possible protective effects of silymarin on valproic acid-induced brain injury by histological and biochemical parameters in rats. The experiment was performed with 21 Sprague Dawley male rats. Rats were divided into three groups: group 1 control, group 2 valproic acid and group 3 valproic acid + silymarin. The groups received valproic acid $500 \mathrm{mg} / \mathrm{kg} /$ day and silymarin $100 \mathrm{mg} / \mathrm{kg} /$ day for 14 days except the control group. Increased serum glucose, cholesterol, triglyceride and creatine kinase BB levels with valproic acid were reversed with silymarin administration. Also, increased malondialdehyde and decreased glutathione levels in brain tissue with valproic acid were significantly suppressed by silymarin. In the valproic acid + silymarin group, oxidative stress was decreased, antioxidant activity was increased and histopathological changes were decreased compared to the valproic acid group. Brain injury caused by valproic acid was attenuated by silymarin treatment owing to the antioxidative and anti-apoptotic effects of silymarin. Silymarin may be useful for reducing the severity of valproic acid induced brain damage.

Keywords: Brain damage, Rat, Silymarin, Valproic acid

öz

\begin{abstract}
Sıçanlarda Silimarinin Beyin Hasarı Üzerine Koruyucu Etkisi
Bu çalışmada silimarin'in sıçanlarda histolojik ve biyokimyasal parametrelerle valproik asite bağlı beyin hasarı üzerindeki olası koruyucu etkilerini değerlendirdik. Deney 21 Sprague Dawley erkek sıçan ile yapıldı. Sıçanlar üç gruba ayrıldı: grup 1 kontrol, grup 2 valproik asit ve grup 3 valproik asit + silimarin. Gruplara kontrol grubu dışında 14 gün boyunca $500 \mathrm{mg} / \mathrm{kg} /$ gün valproik asit ve 14 gün boyunca $100 \mathrm{mg} / \mathrm{kg}$ silimarin verildi. Valproik asit ile artmış serum glikoz, kolesterol, trigliserit ve kreatin kinaz BB seviyeleri, silimarin uygulaması ile tersine çevrildi. Ayrıca, valproik asitle beyin dokusunda artmış malondialdehit ve azalmış glutatyon düzeyleri, silimarin ile anlamlı önemli ölçüde baskılanmıștır. Valproik asit + silimarin grubunda oksidatif stres azaldı, antioksidan aktivite arttı ve valproik asit grubuna göre histopatolojik değişiklikler azaldı. Valproik asidin neden olduğu beyin hasarı, silimarin'in antioksidatif ve anti-apoptotik etkileri nedeniyle silimarin tedavisi ile azaltıldı. Silimarin, valproik asite bağlı beyin hasarının șiddetini azaltmak için yararlı olabilir.
\end{abstract}

Anahtar Kelimeler: Beyin hasarı, Sıçan, Silimarin, Valproik asit

\section{INTRODUCTION}

The formation of reactive oxygen species (ROS) in the brain is a precursor of psychiatric disorders. Because of the brain uses the highest amount of oxygen compared to other body organs, it is very sensitive to oxidative stress. In addition, it produces high amounts of ROS due to its high aerobic metabolism (Nazıroğlu and Yürekli 2013). High amounts of ROS can be important mediators of cell impairment in various structures such as proteins, lipids, nucleic acids, and can alter normal signaling pathways by stimulating redox-sensitive transcription agents (Cárdenas-Rodríguez et al. 2013; Emekli-Alturfan et al. 2015). The role of oxidative stress in the formation of central nervous system (CNS) diseases is well known. This brain contains a large number of oxidized fatty acids and a small number of antioxidant systems. The term epilepsy refers to a group of adult and children disorders characterized by chronic, recurrent, and paroxysmal changes of motor and sensory neurological functions secondary to a disturbance in the electrical activity of a neuron population (Cárdenas-Rodríguez et al. 2013). The onset and progression of epilepsy is caused by free oxygen radicals (Nazıroğlu and Yürekli 2013). Valproic acid (VPA) is used to treat epileptic seizures but also has therapeutic potential in other nervous system diseases such as migraine, manic depression and bipolar disorder (Gynther et al. 2016; Palsamy et al. 2014). VPA binds extensively to plasma proteins, causing serious non-target adverse effects and possible drug-drug interactions (Gynther et al. 
2016). ROS, which occurs as a side-effect in VPA application, can directly damage cellular macromolecules such as DNA, protein, lipids and change the normal signal paths by activation of redox sensitive transcription factors (Emekli-Alturfan et al. 2015). The increased ROS blocks sodium and calcium channels and acts by increasing the function of the inhibitory neurotransmitter gamma aminobutyric acid (GABA). This effect results in a decrease in neuronal activity, an increase in apoptotic cell death in neocortex and a decrease in cell proliferation in ganglional excretion. In addition, it reduces the proliferation of neuroblastoma cells and neural progenitor cells, and induces apoptosis in microglial cells (Eckert et al. 2017; Kataoka et al. 2013).

Phytochemicals and plant-based products are widely used in the treatment of various neurological disorders because of their safety and lack of side effects (Kumburovic et al. 2019). Silymarin (SLY) is a flavonoid obtained from the seeds of milk thistle (Silybum marianum) and widely used as a hepatoprotective agent (Abdelsalam et al. 2019; Gabrielová et al. 2019). SLY has anti-inflammatory, immunomodulator, antifibrotic, antioxidant, metal chelator (iron), protein synthesis stimulant and neuroprotective effects (Gabrielová et al. 2019; Muthumani and Prabu 2014). The SLY is particularly effective in protecting against the effects of inflammatory and oxidative stress caused by neurodegenerative diseases (Borah et al. 2013; Di Costanzo and Angelico 2019). SLY can cross the blood-brain barrier, increase antioxidant enzyme activity and reduce lipid peroxidation levels in erythrocytes exposed to hydrogen peroxide. In addition, SLY supplementation reduces protein oxidation in the cortex and hippocampus of the rat's brain (Yön et al. 2019). SLY acts as a free radical scavenger, removes reactive toxic radicals from oxidative detoxification of xenobiotics and prevents lipid peroxidation (Zhou et al. 2004). SLY has also been reported to be very effective in reducing insulin fibril-induced neuronal toxicity characterized with decreased cell viability, lactate dehydrogenase release, increased intracellular ROS, morphological changes and apoptotic cell death (Katebi et al. 2018). SLY binds to receptors in membranes thus prevents toxins from binding, reduces drug-induced damage, reacts with ROS, converts them to less reactive compounds, enhances the effects of antioxidants GSH (glutathione) (Beydilli et al. 2015; Rašković et al. 2011).

The study was conducted to investigate the preventive effects of SLY against VPA-induced brain damage by evaluating biochemical and histopathological changes.

\section{MATERIALS and METHODS}

\section{Chemicals}

VPA and SLY were purchased from Liba Co (Turkey) and Madaus (Turkey). Hydrochloric acid (HCL), thiochleroacetic acid (TCA), thiobarbuturic acid (TBA) and paraffin were obtained from, Sigma-Aldrich (USA). Xylene, hematoxylin-eosin and ethanol were obtained from Merck (Germany). All other chemicals were the best analytical grade and were purchased from Sigma.

\section{Animals}

In this study 21 male Sprague-Dawley rats $(220-250 \mathrm{~g}$, for 8 weeks) were obtained from Adiyaman University Experimental Animal Production Application and Research Center and the study was conducted at the same place. Ethics committee report; it was obtained from the Laboratory Animals Ethics Committee (Protocol 2019/08) of Firat University Faculty of Medicine and the study was conducted according to this protocol.

\section{Treatment protocol}

The animals were randomised into three groups, with seven rats in each group, as follows: Control; VPA; VPA + SLY. The control group received $0.5 \mathrm{~mL}$ saline i.p. and $1 \mathrm{~mL}$ saline orally for 14 days. VPA group received 500 $\mathrm{mg} / \mathrm{kg} /$ day VPA p.o. for 14 days (Tong et al. 2005). VPA + SLY group received $500 \mathrm{mg} / \mathrm{kg} /$ day VPA p.o. and 100 $\mathrm{mg} / \mathrm{kg} /$ day SLY p.o. for 14 days (Beydilli et al. 2015). Rats were sacrificed by cervical dislocation under anesthesia with ethyl ether at the end of day 14. Blood samples were collected from the jugular vein, centrifuged at 5,000 $\mathrm{x}$ for 15 minutes, and serum was collected and stored at $-86^{\circ} \mathrm{C}$ for biochemical analysis. The brain was excised and stored at $-86^{\circ} \mathrm{C}$ until analysis.

\section{Biochemical evaluation}

Serum biochemical parameters glucose $\mathrm{mg} / \mathrm{dL}$, cholesterol $\mathrm{mg} / \mathrm{dL}$, triglyceride (TG) $\mathrm{mg} / \mathrm{dL}$ and creatine kinase $\mathrm{BB}$ (CK BB) $\mathrm{mg} / \mathrm{dL}$ ) were analyzed according to ReitmanFrankel colorimetric transaminase method on Olympus 2700 analyzer at the University of Adiyaman (Olympus Diagnostica GmbH, Hamburg, Germany) (Crowley 1967).

\section{Oxidative stress biomarkers}

Malondialdehyde (MDA) measurements were made in brain tissue. Two volumes of sample and two volumes of stock solution $(0.375 \%$ thiobarbituric acid in $0.25 \mathrm{~N} \mathrm{HCl}$ and $15 \%$ trichloroacetic acid) were mixed in the centrifuge tube. The solution was heated for 15 minutes in boiling water and then cooled. The residue was centrifuged at $2500 \mathrm{x} \mathrm{g}$ for 10 minutes and samples were read by spectrophotometer at a wavelength of $532 \mathrm{~nm}$ (Placer et al. 1966).

GSH levels in brain tissues were determined according to Sedlak and Lindsay method (Sedlak and Lindsay 1968). The sample was eluted with 50\% TCA and centrifuged at $1000 \mathrm{x} g$ for 5 minutes. $2 \mathrm{~mL}$ Tris-EDTA buffer $(0.2 \mathrm{M}, \mathrm{PH}=$

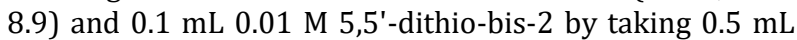
of the supernatant from the supernatant-nitrobenzoic acid was added. The mixture sample was allowed to stand at room temperature for 5 minutes and read by spectrophotometer at $412 \mathrm{~nm}$ wavelength.

\section{Histopathological examinations}

The brain tissues taken from animals were fixed in $10 \%$ neutral formalin solution. After fixation tissues were washed overnight in running water. These washed samples were dehydrated with ethanol, cleared with xylene and embedded in paraffin. 4-5 $\mu \mathrm{m}$ thick sections were taken from the paraffin blocks (RM2125RTS, Leica, Germany). The samples from all groups were stained with hematoxylin \& eosin for histopathological evaluation. The histopathological findings were evaluated under these parameters; neuronal structure (nuclear and cytoplasm properties) and neuroglial changes (number and morphology). Histopathological scoring was performed in terms of apoptotic (dense eosinophilic cytoplasm, picnotic nucleus, apoptotic bodies) and regenerative findings (reduction in apoptotic cell count, neuroglial aggregation, large neuroglial cells with vesicular nuclei) by examining different areas in $40 \mathrm{x}$ objective from each section. According to the grade of the findings (-): no findings, $(+)$ : low level, $(++)$ : moderate level, $(+++)$ : severe level. Samples were evaluated and imaged by imaging binocular light microscopy (ECLIPSE Ni-U, Nikon and Tokyo, Japan). (Mostafa et al. 2017) 


\section{Statistical analysis}

SPSS version 20.0 was used for statistical analysis. Shapiro-Wilk test was used to evaluate normality. Oneway ANOVA and post-hoc, LSD were applied for in-group comparisons of parametric data; Kruskal Wallis test was used for non-parametric of biochemical data. The same test was also used for semi-qualified evaluation of histopathological scores and for differences in the data measured between the groups. Mann-Whitney $U$ test was used to compare the two groups. Data were considered statistically significant for $p \leq 0.05$.

\section{RESULTS}

\section{Biochemical evaluation}

Glucose, cholesterol, TG and CK BB levels were significantly increased in VPA group compared to control and VPA + SLY groups. SLY therapies resulted in a significant decrease in VPA-induced glucose, cholesterol, TG and CK BB levels (Table 1).

\section{Oxidative stress biomarkers}

According to the data in Table 1, significantly higher MDA level and significantly lower GSH levels were detected in the VPA group. SLY treatments resulted in a significant decrease in MDA level and a significant increase in GSH level.

\section{Histopathological results}

As shown Table 2 and Figure 1, examination of sections from control group showed normal neuronal structure. The staining characteristics of nucleosus-cytoplasm and morphology of neurons was normal. Also neuroglial cells were in normal number and morphology (Fig. $1 \mathrm{~A}, \mathrm{~B}$ ). In VPA group there were significant pathological changes; many apoptotic bodies and apoptotic neurons/neuroglial cells with dense eosinophilic cytopalsm and picnotic nuclei (Fig. 1 C, D). Compared to the VPA group, a significant improvement was observed in histopathological findings in the VPA + SLY group. In sections of VPA + SLY group, neuroglial cell clusters and neuroglial cells with large vesicular nuclei were observed as a sign of regeneration with decreased number of apoptotic cells (Fig. 1 E, F).

Table 1. Serum biochemical and tissue oxidative stress biomarkers in brain of experimental groups

\begin{tabular}{|c|c|c|c|}
\hline & Control & VPA & VPA + SLY \\
\hline & \multicolumn{3}{|c|}{ Serum biochemical biomarkers } \\
\hline Glucose (mg/dL) & $123.14 \pm 1.58 \mathrm{~b}$ & $145.29 \pm 1.26^{\mathrm{a}, \mathrm{c}}$ & $125.14 \pm 1.20 \mathrm{~b}$ \\
\hline Cholestrol (mg/dL) & $50.00 \pm 1.29 \mathrm{~b}$ & $65.00 \pm 1.54 \mathrm{a}, \mathrm{c}$ & $51.86 \pm 0.50 \mathrm{~b}$ \\
\hline Trigleyceride (mg/dl) & $70.00 \pm 1.19 \mathrm{~b}, \mathrm{C}$ & $11.43 \pm 1.51 \mathrm{a}, \mathrm{c}$ & $80.00 \pm 0.81 \mathrm{a}, \mathrm{b}$ \\
\hline \multirow[t]{2}{*}{$\begin{array}{l}\text { Creatine Kinase-BB } \\
(\mathrm{mg} / \mathrm{dL})\end{array}$} & $24.71 \pm 1.01 \mathrm{~b}$ & $64.71 \pm 1.71 \mathrm{a}, \mathrm{c}$ & $28.29 \pm 2.36^{b}$ \\
\hline & \multicolumn{3}{|c|}{ Heart tissue oxidative stress biomarkers } \\
\hline GSH (nmole/mg) & $130.00 \pm 2.44 \mathrm{a}, \mathrm{b}$ & $70.00 \pm 2.52 \mathrm{a}, \mathrm{c}$ & $121.43 \pm 2.68 \mathrm{a}, \mathrm{b}$ \\
\hline $\begin{array}{l}\text { MDA (nmole/mg } \\
\text { tissue) }\end{array}$ & $39.71 \pm 2.45 \mathrm{~b}, \mathrm{c}$ & $171.43 \pm 2.54 \mathrm{a}, \mathrm{c}$ & $120.02 \pm 2.67 \mathrm{a}, \mathrm{b}$ \\
\hline
\end{tabular}

Table 2. Histopathological scoring of brain sections of experimental groups

\begin{tabular}{lccc}
\multicolumn{1}{c}{ Parameters/scores } & Control & VPA & VPA+SLY \\
\hline Apoptotic Findings & & & ++ b \\
\hline - dense eosinophilic cytoplasm & - & $+++^{\mathrm{a}}$ & $++\mathrm{b}$ \\
- picnotic nucleus & - & $+++^{\mathrm{a}}$ & $++\mathrm{b}$ \\
- apoptotic bodies & - & ++ a & $+++\mathrm{b}$ \\
\hline Regenerative Findings & - & $-\mathrm{a}$ & $+++\mathrm{b}$ \\
\hline - reduction in apoptotic cell count & - & $-\mathrm{a}$ & $+++\mathrm{b}$ \\
- neuroglial aggregation & - & $-\mathrm{a}$ & \\
- large neuroglial cells with vesicular nuclei & - & \\
\hline
\end{tabular}

In according to modified semi-quantitative scale for the evaluation of histopathological changes; (0): none, (1): mild, (2): moderate, (3): severe grade ( $\mathrm{n}=7$ ). VPA, valproic acid; SLY, silymarin; a: VPA increased brain damage, $p<0.05$ vs. control group. b: SLY reduced brain damage, $p<0.05$ vs. VPA group 


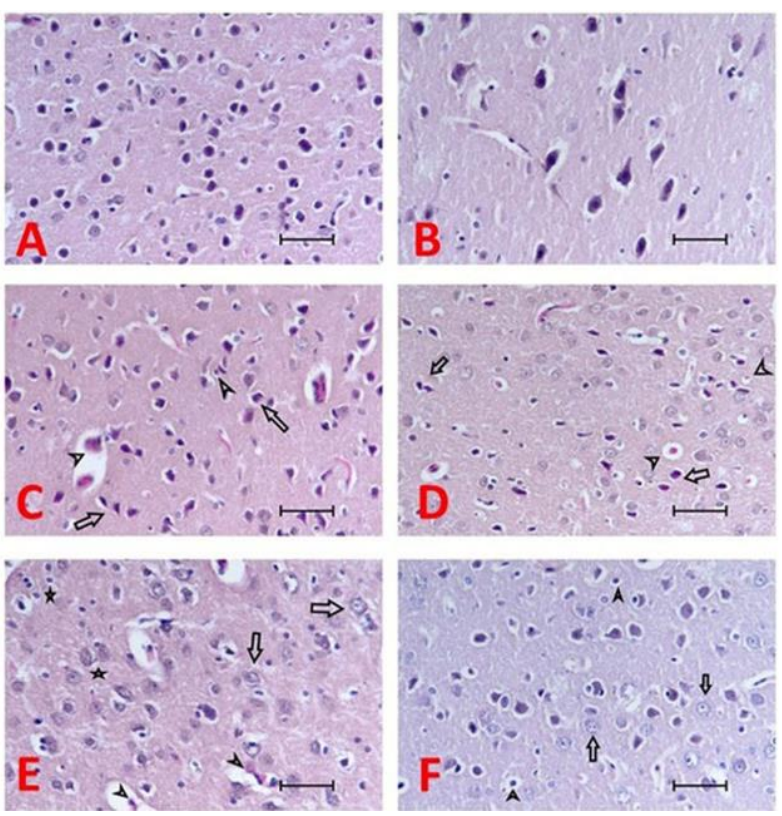

Figure 1. Rat brain tissue section. A-B; Control group; normal histological appearance is observed in brain tissue sections. C-D; VPA given to the group; Many apoptotic cells (arrows) and apoptotic bodies (arrowheads) are seen in different cortex tissue regions of the brain. E-F; VPA + SLY given group; A small number of apoptotic cells (arrowheads), a large number of large vesicular neuroglial cells (arrows) and neuroglial clusters are observed in sections of SLY group (asterisk). Showed decrease of histopathological findings compared to VPA group (H-E, Scale bar $50 \mu \mathrm{m}, \mathrm{x} 400$ )

\section{DISCUSSION}

Brain tissue is exposed to neuronal death because of ROSinduced damage due to its high oxidative metabolism and less antioxidant defense system than other organs (Demirel Yılmaz 2019; Nazıroğlu and Yürekli 2013). Oxidative stress, because of this cycle, plays an important role in the pathophysiology of epilepsy. Increased free radicals and decreased GSH concentrations have been reported in membrane lipid peroxidation in the epileptic focus. Increasing evidences suggest that long-term antiepileptic drug therapy leads to increased oxidative stress. For example, VPA has been reported to increase lipid peroxidation and thus cause brain damage in longterm users (Chaudhary and Parvez 2018; Nazıroğlu and Yürekli 2013). Indeed, VPA has been reported to exacerbate the death of cerebellar granular neurons, induce cognitive impairment in various neuronal cell populations and reduce the proliferation of hippocampal neurons that induce apoptosis (Bollino et al. 2015). To date, different antioxidant agents have been used to decrease the toxic effect of VPA. However, there is little data on the protective effect of SLY on VPA-induced brain injury. It has been reported that SLY plays a role in the protection of neurons against oxidative stress and has a direct effect on neuronal oxidant status. SLY has been reported to balance oxidative stress and neurotoxicity by increasing the activity of both enzymatic and nonenzymatic antioxidant markers.

In addition, SLY has been reported to be protective against oxidative insults by potentially inhibiting the formation of oxygen and peroxyl radicals along with protein oxidation products in the cortices of the elderly rodent brain. In another study, it was reported that application of SLY increases respiratory activity and inhibits lipid peroxidation in brain mitochondria (Borah et al. 2013). According to recent studies, SLY has been reported to react with ROS as an antioxidant to form less reactive and toxic compounds and to increase resistance to harmful effects by interacting with cell membranes (Rašković et al. 2011). As a result, SLY acts primarily as an antioxidant, reduces ROS and lipid peroxidation and increases endogenous antioxidant enzyme concentrations (de Avelar et al. 2017).

An increase in biochemical parameters suggests that 4-enVPA and its $\beta$-oxidation products trigger a series of reactions that result in accumulation (Abdel-Dayem et al. 2014). Serum glucose level increased slightly with VPA administration, which approached normal with SLY administration. In a study of 25 patients, a significant reduction in blood sugar levels occurred after four months of treatment with $200 \mathrm{mg}$ SLY three times a day before meals (Huseini et al. 2006). This study is compatible with our study. It was seen that total serum cholesterol levels which were reported to be increased by VPA were then lowered by SLY. SLY applies antioxidant and membrane stabilizing activity. This effect contains important properties for uptake of plasma lipoproteins and thus changes in lipid metabolism. In addition, SLY has been reported to have a direct effect on cholesterol metabolism by inhibiting a reductase enzyme, 3-hydroxy 3methylglutaryl CoA, involved in cholesterol synthesis (Metwally et al. 2009; Neha et al. 2014). In a study, Metwally et al. (2009) lowered the level of cholesterol in proportion to SLY in rats fed high-cholesterol diet. The cholesterol lowering effect of SLY parallels our study. Increased TG levels with VPA were reversed with SLY and our study is consistent with the literature. VPA-induced high TG level may be attributed to inhibition of endothelial lipoprotein lipase activity responsible for the hydrolysis of TG. In a study of rats, Ali et al. (2019) shows that giving FRAL (fructose $(10 \%)$ in drinking water plus AlCl3 (34 $\mathrm{mg} / \mathrm{kg} /$ day)) significantly increased serum $\mathrm{TG}$ level to normal rats. FRAL + SLY $(100 \mathrm{mg} / \mathrm{kg} /$ day $)$ per oral gavage administration resulted in a significant decrease in serum TG level compared to FRAL + SLY. The results obtained in this study are parallel to the effect of SLY on TG.

CK-BB is a creatine-kinase isoform found in CNS. This enzyme catalyzes the transfer of phosphate groups from ATP to creatine phosphate, so it plays a role in energy transfer in tissues with large energy demands, such as the brain. Inside the CNS, CK-BB is found in astrocytes and is therefore released when there is brain tissue damage. Serum CK-BB levels have been found to be high in a variety of brain injury environments, including cardiac arrest or subarachnoid hemorrhage (Sharma et al. 2017). Because of VPA application, CK-BB level was increased. This may be due to impaired energy transfer due to accumulation of VPA in the brain. With the SLY application, the situation is reversed.

GSH is an endogenous antioxidant which is mainly present in reduced form in cells. It reacts with free radicals and inactivates them and their most toxic form, hydroxyl radicals, in oxidized form (Agarwalet al. 2011). In our study, we found a significant decrease in GSH levels as a result of oxidative stress caused by VPA application. It caused the depletion of antioxidants (GSH) in neuronal cells because of cellular redox formation and endogenous ROS accumulation created by VPA. In addition, neurotoxicity develops by increasing the sensitivity of the neuronal plasma membrane to free radical attacks (Chaudhary and Parvez 2018). Wu et al. (2017) in the study of pregnant rats, embryonic day $12.5 \mathrm{ip} 600 \mathrm{mg} / \mathrm{kg}$ 
VPA single dose exposure females. SLY increased ROS scavenging activity, cellular content of GSH, and membrane stability. The decreasing GSH level increased with SLY due to the effect of the oxidative stress formed by I/R. These study compatibles with our study (Moghaddam et al. 2020).

Lipid peroxidation is the process that involves chain reactions of free radicals with polyunsaturated fatty acids. These reactions lead to hydroperoxide formation and lipid cleavage into low molecular weight fragments. MDA is a large reactive aldehyde resulting from the peroxidation of biological membrane-polyunsaturated fatty acids. Therefore, it is used as an indicator of tissue damage, which includes a series of chain reactions (Wu et al. 2017). Gao et al. (2016), in their study, observed high MDA because of increased oxidative stress in the brain of VPAinduced rat pups. In this toxicity, high ROS in the neurons of the hippocampus and cerebral cortex are signs of tissue damage and reduced antioxidant protection mechanisms. In another study, SLY increased the activity of enzymes that neutralize lipid peroxidation and decreased the level of MDA to normal values (Zhu et al. 2014).

There are various data indicating that VPA, which is widely used as an anticonvulsant agent, causes neurodegeneration in long term uses. Especially VPA has been shown to cause serious problems including coma and cerebral edema due to neurotoxic effects on the central nervous system (Camilleri et al. 2005). In accordance with these data, both in vitro and in vivo studies reveal neurodegeneration caused by VPA (Fujiki et al. 2013; Jin et al. 2005). In our study, histopathological examinations in the brain tissue were carried out for the detection of neurodegenerative and regenerative findings. When the sections belonging to the treatment groups were examined, as a result of the effect of SLY, the presence of findings that could be evaluated in favor of regeneration (neuroglial clustering, large neuroglial cells with vesicular nuclei) was observed with the decrease in the findings of apoptotic neurodegeneration. These data show that histopathologically, VPA causes apoptotic neurodegeneration and SLY leads to an improvement in apoptotic neurodegeneration findings.

Free radicals and oxidative stress have an important place among the possible mechanisms of VPA in apoptotic neurodegeneration (Zhang et al. 2010). There are many studies showing that oxidative stress is responsible for various neurodegenerative diseases and also demonstrating the neuroprotective effects of various antioxidants (Chaudhary and Parvez 2018). When histopathological findings are evaluated together with other results, it is seen that VPA causes an apoptotic neurodegeneration caused by oxidative stress and SLY causes a decrease in these findings with antioxidant effects.

\section{CONCLUSION}

Treatment with SLY inhibited VPA induced brain dysfunction and histopathological changes significantly. The antioxidant and anti-apoptotic activities of SLY appear to be responsible for its brain protective effect. Therefore, SLY may useful for attenuation or prevention of the complications of VPA induced brain injury in clinical practice.

\section{CONFLICT of INTEREST}

The authors declare that they have no conflict of interest.

\section{REFERENCES}

Abdel-Dayem MA, Elmarakby AA, Abdel-Aziz AA, Pye C, Said SA, ElMowafy AM (2014). Valproate-induced liver injury: modulation by the omega-3 fatty acid DHA proposes a novel anticonvulsant regimen. Drugs $R$ D, 14(2), 85-94.

Abdelsalam HM, Samak MA, Alsemeh AE (2019). Synergistic therapeutic effects of Vitis vinifera extract and Silymarin on experimentally induced cardiorenal injury: The pertinent role of Nrf2. Biomed Pharmacother, 110, 37-46.

Agarwal NB, Agarwal NK, Mediratta PK, Sharma KK (2011). Effect of lamotrigine, oxcarbazepine and topiramate on cognitive functions and oxidative stress in PTZ-kindled mice. Seizure, 20(3), 257-62.

Ali NM, Mahmoud AAA, Mahmoud MF, El Fayoumi HM (2019). Glycyrrhizic acid and silymarin alleviate the neurotoxic effects of aluminum in rats challenged with fructose-induced insulin resistance: possible role of toll-like receptor 4 pathway. Drug Chem Toxicol, 42(2), 210-9.

Beydilli H, Yilmaz N, Cetin ES et al. (2015). Evaluation of the protective effect of silibinin against diazinon induced hepatotoxicity and freeradical damage in rat liver. Iran Red Crescent Med J, 17 (4), 1-7.

Bollino D, Balan I, Aurelian L (2015). Valproic acid induces neuronal cell death through a novel calpain-dependent necroptosis pathway. $J$ Neurochem, 133(2), 174-86.

Borah A, Paul R, Choudhury S et al. (2013). Neuroprotective potential of silymarin against CNS disorders: Insight into the pathways and molecular mechanisms of action. CNS Neurosci Ther, 19(11), 847-53.

Camilleri C, Albertson T, Offerman S (2005). Fatal cerebral edema after moderate valproic acid overdose. Ann Emerg Med, 45(3), 337-8.

Cárdenas-Rodríguez N, Coballase-Urrutia E, Rivera-Espinosa $L$ et al. (2013). Modulation of antioxidant enzymatic activities by certain antiepileptic drugs (valproic acid, oxcarbazepine, and topiramate): Evidence in humans and experimental models. Oxid Med Cell Longev, 2013, 598-493.

Chaudhary S, Parvez S (2018). Valproic acid induced neurotoxicological manifestations and its mitigation by melatonin in rat brain synaptosomes. Arch Med Res, 49(7), 441-50.

Crowley LV (1967). The reitman-frankel colorimetric transaminase procedure in suspected myocardial infarction. Clin Chem, 13(6), 482-7.

de Avelar CR, Pereira EM, de Farias Costa PR, de Jesus RP, de Oliveira LPM (2017). Effect of silymarin on biochemical indicators in patients with liver disease: Systematic review with meta-analysis. World $J$ Gastroenterol, 23(27), 5004-17.

Demirel Yılmaz B, Eren B, Sağır D, Eren Z, Başardı Gökçe A (2019). Stereological examination of curcumin's effects on hippocampal damage caused by the anti-epileptic drugs phenobarbital and valproic acid in the developing rat brain. Acta Histochem, 121(4), 430-6.

Di Costanzo A, Angelico R (2019). Formulation strategies for enhancing the bioavailability of silymarin: The state of the art. Molecules, 24(11), $1-29$.

Eckert M, Klumpp L, Huber S (2017). Cellular effects of the antiepileptic drug valproic acid in glioblastoma. Cell Physiol Biochem, 44(4), 1591605.

Emekli-Alturfan E, Alev B, Tunali S et al. (2015). Effects of edaravone on cardiac damage in valproic acid induced toxicity. Ann Clin Lab Sci, 45(2), 166-72.

Fujiki R, Sato A, Fujitani M. Yamashita T. (2013). A proapoptotic effect of valproic acid on progenitors of embryonic stem cell-derived glutamatergic neurons. Cell death \& disease, 4(6), 677-87.

Gabrielová E, Zholobenko AV, Bartošíková L, Nečas J, Modriansky M (2015). Silymarin constituent 2,3-dehydrosilybin triggers reserpinesensitive positive inotropic effect in perfused rat heart. PLoS One, $10(9), 1-15$.

Gao J, Wang X, Sun $\mathbf{H}$ et al. (2016). Neuroprotective effects of docosahexaenoic acid on hippocampal cell death and learning and memory impairments in a valproic acid-induced rat autism model. Int J Dev Neurosci, 49, 67-78.

Gynther M, Peura L, Vernerová M et al. (2016). Amino acid promoieties alter valproic acid pharmacokinetics and enable extended brain exposure. Neurochem Res, 41(10), 2797-809.

Huseini HF, Larijani B, Heshmat R et al. (2006). The efficacy of Silybum marianum (L.) Gaertn. (silymarin) in the treatment of type II diabetes: a randomized, double-blind, placebo-controlled, clinical trial. Phytother Res, 20(12),1036-9.

Jin N, Kovács AD, Sui Z, Dewhurst S, Maggirwar SB (2005). Opposite effects of lithium and valproic acid on trophic factor deprivationinduced glycogen synthase kinase- 3 activation, c-Jun expression and neuronal cell death. Neuropharmacology, 48(4), 576-83.

Kataoka S, Takuma K, Hara Y, Maeda Y, Ago Y, Matsuda T (2013). Autism-like behaviours with transient histone hyperacetylation 
in mice treated prenatally with valproic acid. Int $J$ Neuropsychopharmacol, 16(1), 91-103.

Katebi B, Mahdavimehr M, Meratan AA, Ghasemi A, Nemat-Gorgani M (2018). Protective effects of silibinin on insulin amyloid fibrillation, cytotoxicity and mitochondrial membrane damage. Arch Biochem Biophys, 659, 22-32.

Kumburovic I, Selakovic D, Juric T et al. (2019). Antioxidant effects of satureja hortensis L. attenuate the anxiogenic effect of cisplatin in rats. Oxid Med Cell Longev, 2019, 1-15.

Metwally MAA, El-Gellal AM, El-Sawaisi SM (2009). Effects of Silymarin on Lipid Metabolism in Rats. World Applied Sciences Journal, 6 (12), 1634-7

Moghaddam AH, Mokhtari Sangdehi SR, Ranjbar M, Hasantabar V (2020). Preventive effect of silymarin-loaded chitosan nanoparticles against global cerebral ischemia/reperfusion injury in rats. Eur $J$ Pharmacol, 3, 877-86.

Mostafa HE, Alaa-Eldin EA, El-Shafei DA, Abouhashem NS (2017) Alleviative effect of licorice on copper chloride-induced oxidative stress in the brain: biochemical, histopathological, immunohistochemical, and genotoxic study. Environ Sci Pollut Res Int 24(22), 18585-95

Muthumani M, Prabu SM (2014). Silibinin potentially attenuates arsenicinduced oxidative stress mediated cardiotoxicity and dyslipidemia in rats. Cardiovasc Toxicol, 14(1), 83-97.

Nazıroğlu M, Yürekli, VA (2013). Effects of antiepileptic drugs on antioxidant and oxidant molecular pathways: Focus on trace elements. Cell Mol Neurobiol, 33(5), 589-99.

Neha, Kumar A, Jaggi AS, Sodhi RK, Singh N (2014). Silymarin ameliorates memory deficits and neuropathological changes in mouse model of high-fat-diet-induced experimental dementia. Naunyn Schmiedebergs. Arch Pharmacol, 387(8), 777-87.

Palsamy P, Bidasee KR, Shinohara T (2014). Valproic acid suppresses Nrf2/Keap1 dependent antioxidant protection through induction of endoplasmic reticulum stress and Keap1 promoter DNA demethylation in human lens epithelial cells. Exp Eye Res, 121, 26-34.
Placer ZA, Cushman LL, Johnson BC (1966). Estimation of product of lipid peroxidation (malonyl dialdehyde) in biochemical systems. Anal Biochem, 16(2), 359-64.

Rašković A, Stilinović N, Kolarović J, Vasović V, Vukmirović S, Mikov M (2011). The protective effects of silymarin against doxorubicininduced cardiotoxicity and hepatotoxicity in rats. Molecules, 16(10), 8601-13.

Sedlak J, Lindsay RH (1968). Estimation of total, protein-bound, and nonprotein sulfhydryl groups in tissue with Ellman's reagent. Anal Biochem, 25(1), 192-205.

Sharma R, Rosenberg A, Bennett ER, Laskowitz DT, Acheson SK (2017). A blood-based biomarker panel to risk-stratify mild traumatic brain injury. PLoS One, 12(3), e0173798.

Tong V, Teng XW, Chang TKH, Abbott FS (2005). Valproic cid I: Time course of lipid peroxidation biomarkers, liver toxicity, and valproic acid metabolite levels in rats. Toxicol Sci, 86(2), 427-35.

Wu H, Wang X, Gao J et al. (2017). Fingolimod (FTY720) attenuates social deficits, learning and memory impairments, neuronal loss and neuroinflammation in the rat model of autism. Life Sci, 173, 43-54.

Yön B, Belviranlı M, Okudan N (2019). The effect of silymarin supplementation on cognitive impairment induced by diabetes in rats. J Basic Clin Physiol Pharmacol, 30(4), 1-9.

Zhu SY, Dong Y, Tu J, Zhou Y, Zhou XH, Xu B (2014). Silybum marianum oil attenuates oxidative stress and ameliorates mitochondrial dysfunction in mice treated with D-galactose. Pharmacogn Mag, 10, 92-9.

Zhou S, Lim LY, Chowbay B (2004). Herbal Modulation of P-Glycoprotein. Drug Metab Rev, 36(1), 7-104.

Zhang B, Wang X, Nazarali AJ (2010). Ascorbic acid reverses valproic acid-induced inhibition of hoxa2 and maintains glutathione homeostasis in mouse embryos in culture. Cell Mol Neurobiol, 30(1), 137-48. 